\title{
Aberrant expression of EZH2 is associated with a poor outcome and P53 alteration in squamous cell carcinoma of the esophagus
}

\author{
ATSUSHI YAMADA ${ }^{1,3}$, SATOSHI FUJII $^{1}$, HIROYUKI DAIKO ${ }^{2}$, MITSUYO NISHIMURA $^{2}$, \\ TSUTOMU CHIBA $^{3}$ and ATSUSHI OCHIAI ${ }^{1}$
}

\begin{abstract}
${ }^{1}$ Pathology Division, Research Center for Innovative Oncology, ${ }^{2}$ Department of Surgery, National Cancer Center Hospital East, 6-3-1 Kashiwanoha, Kashiwa, Chiba 277-8577; ${ }^{3}$ Department of Gastroenterology and Hepatology, Graduate School of Medicine, Kyoto University, 54 Shogoin-kawara-cho, Sakyo-ku, Kyoto 606-8507, Japan
\end{abstract}

Received May 18, 2010; Accepted August 13, 2010

DOI: $10.3892 / \mathrm{ijo} .2010 .868$

\begin{abstract}
EZH2 and BMI1 are transcriptional repressors and have been implicated in the progression of human cancers. Squamous cell carcinoma of the esophagus (ESCC) is one of the most aggressive carcinomas in the gastrointestinal tract and generally has an unfavorable outcome. In the present study, we immunohistochemically investigated the expression of EZH2 and BMI1 in 136 surgically resected ESCCs and adjacent epithelium. We also analyzed associations between aberrant expression of EZH2 and BMI1, and both clinicopathological findings and outcome. MYC, RB, and P53 expression was examined in selected cases and analyzed in relation to EZH2 expression. Mutations in the P53 gene were evaluated by direct sequencing. EZH2 mRNA expression was investigated in ESCC cell lines with and without P53 transcriptional activity. The results showed that $\mathrm{EZH} 2$ protein and BMI1 protein were upregulated in ESCC tissue in comparison with adjacent non-neoplastic epithelium. Aberrant EZH2 and BMI1 protein expression was observed in 19 (14.0\%) and 23 (16.9\%), respectively, of the 136 ESCCs. Aberrant EZH2 expression was significantly associated with larger size, greater depth of invasion, presence of distant metastasis, and shorter disease-free survival time. Aberrant BMI1 expression was inversely associated with lymph node metastasis and venous invasion, but not associated with survival of the patients. In addition, aberrant EZH2 expression was associated with P53 alteration in ESCC tissue. EZH2 mRNA expression in ESCC cell lines was reduced by activation of P53. In conclusion, P53 alteration may be involved in dysregulated EZH2 expression, and aberrant expression of EZH2 may play a role in ESCC progression.
\end{abstract}

Correspondence to: Dr Atsushi Ochiai, Pathology Division, Research Center for Innovative Oncology, National Cancer Hospital East, 6-3-1 Kashiwanoha, Kashiwa, Chiba 277-8577, Japan

E-mail: aochiai@east.ncc.go.jp

Key words: EZH2, BMI1, squamous cell carcinoma of the esophagus, P53

\section{Introduction}

EZH2 and BMI1 are members of the polycomb group of proteins, which function as transcriptional repressors through chromatin modification. EZH2 composes polycomb repressive complex (PRC) 2 with other members, while BMI1 is a component of PRC1 (1). Previous studies have shown that EZH2 is highly expressed in prostate cancer (2) and breast cancer (3) and that its expression is associated with a poor outcome of both $(4,5)$. Increased expression of EZH2 and a relation to poor outcome have been also reported in regard to other cancers, including colorectal cancer (6), stomach cancer (7), and oral squamous cell carcinoma (8).

EZH2 is implicated in cell proliferation and cell cycle regulation. Inhibition of EZH2 expression by small interfering RNA (siRNA) results in inhibition of cell proliferation, cell cycle arrest, and reduced cancer cell invasiveness (2,9-12). Overexpression of EZH2 promotes cell proliferation, anchorage-independent growth, and cell invasion in vitro $(3,11,13)$. Although the precise mechanism by which EZH2 contributes to these malignant phenotypes of cancers has not been fully elucidated, EZH2 is suspected of playing a role in the repression of tumor suppressor genes such as the genes encoding DAB2IP (14), E-cadherin (15), and RUNX3 (16).

Expression of EZH2 has been reported to be regulated by the P53-RB-E2F pathway $(9,10)$, MYC (17), microRNA-26a $(17,18)$, and microRNA-101 (19). In addition, a recent study showed a correlation between P53 mutation and EZH2 expression in breast cancer tissue (20).

BMI1 has also been reported to be overexpressed in several human cancer types (21-26). BMI1 knockdown by siRNA results in inhibition of cell proliferation (23-25), the same as knockdown of EZH2. Thus, the polycomb group proteins EZH2 and BMI1 have been implicated in the progression of human cancers, and both proteins have been regarded as possible targets of treatment (27-30).

Squamous cell carcinoma of the esophagus (ESCC) is one of the most aggressive carcinomas in the gastrointestinal tract and generally has an unfavorable outcome. Mutation of the $P 53$ gene is a frequent and early event in the carcinogenesis of ESCC (31-34), and amplification of MYC and $\mathrm{LOH}$ and/or absence of expression of RB have also been reported (31). 
We conducted this study with the aim of determining the significance of EZH2 and BMI1 protein expression in relation to both the clinicopathological findings and outcome in a series of ESCC cases treated with surgical resection. We also tried to identify factors involved in dysregulation of EZH2 expression.

\section{Patients and methods}

Patients and follow-up. A total of 136 consecutive ESCC patients who underwent surgical resection with curative intent between January 1992 and December 2003 at the National Cancer Center Hospital East were enrolled in this study. Patients with simultaneous multiple esophageal cancers, with an uncontrolled malignant tumor in another organ, who received any adjuvant therapy prior to surgery, who died within 30 days after surgery, and whose lesions were inadequately immunostained were excluded. This study was approved by the Institutional Review Board at the National Cancer Center, and written informed consent was obtained from all patients.

There were 114 men and 22 women, and their median age was 62 years (range 40-78). Clinicopathological findings were assessed based on the International Union Against Cancer (UICC) TNM staging system (35). There were 35 stage I cases, 19 stage IIA cases, 32 stage IIB cases, 44 stage III cases, and 6 stage IV cases. According to the histologic grade criteria of the World Health Organization (31), 12 (9\%) cases were classified in well differentiated, $99(73 \%)$ cases as moderately differentiated, and 25 (18\%) cases as poorly differentiated.

The median follow-up period of the surviving patients was 71.5 months (range 2-164). The median overall survival time and disease-free survival time were 57 months (range 1-164) and 52.5 (1-158) months, respectively. The 5-year overall survival rate was $61.9 \%$.

Immunohistochemistry. All resected specimens were fixed in either $10 \%$ formalin or methanol, and embedded in paraffin. Sections ( $3 \mu \mathrm{m}$ thick) were cut from the paraffin-embedded block that contained the most representative area of the tumor and were used for immunohistochemical staining. Blocks which contained representative area of the tumor as well as non-neoplastic esophageal epithelium adjacent to the tumor were chosen when available. The sections were deparaffinized in xylene, dehydrated in a graded series of ethanol, and immersed for $15 \mathrm{~min}$ in methanol containing $0.3 \%$ hydrogen peroxide to inhibit endogenous peroxidase activity. For antigen retrieval, the slides were autoclaved in Tris-EDTA buffer (pH 9.0) at $121^{\circ} \mathrm{C}$ for $15 \mathrm{~min}(\mathrm{EZH} 2$, $\mathrm{BMI} 1, \mathrm{MYC}$, and $\mathrm{RB}$ ) or heated in citrate buffer ( $\mathrm{pH} 6.0$ ) at $95^{\circ} \mathrm{C}$ for $20 \mathrm{~min}$ in a microwave oven (P53), and then allowed to cool to room temperature. Non-specific binding was blocked by preincubation with $2 \%$ normal swine serum in phosphate-buffered saline (PBS) for $60 \mathrm{~min}$ at room temperature. After incubating the slides with the respective primary antibodies overnight at $4^{\circ} \mathrm{C}$, they were washed three times with PBS and incubated with EnVision (Dako) for $1 \mathrm{~h}$ at room temperature. The sections were visualized by using 3,3'-diaminobenzidine tetrahydrochloride in $50 \mathrm{mM}$ Tris-buffer ( $\mathrm{pH} 7.6$ ) containing $0.3 \%$ hydrogen peroxide as the chromogen, and counterstained with hematoxylin. The antibodies used in this study were anti-EZH2 (mouse monoclonal, clone 11, BD Biosciences, 1:25), anti-BMI1 (mouse monoclonal, clone F6, Upstate, 1:25), anti-MYC (mouse monoclonal, clone 9E10, Santa Cruz Biotechnology, 1:500), anti-RB (mouse monoclonal, clone 1F8, Thermo Scientific, 1:500), and antiP53 (mouse monoclonal, clone DO-7, Dako, 1:50). Negative controls were prepared by omitting the primary antibodies.

To assess EZH2 and BMI1 protein expression, a minimum of 500 cells in each tumor and adjacent non-neoplastic esophageal epithelium were counted, and the percentages of cells with positive nuclear staining were recorded. Only nuclei in which expression was as at least as intense as in the lymphocytes in the same section, which served as an internal positive control, were considered positive, and ESCC tissue in which $5 \%$ or more of the cancer cells were positive was considered to positive for aberrant expression of the respective protein. Expression of MYC and RB was evaluated by examining at least 500 cancer cells, and the percentages of cells with positive nuclear staining were recorded. Each case was then classified into a high-expression group ( $\geq$ median) or a low-expression group (< median). P53 staining was considered positive when $>10 \%$ of the cells showed strong nuclear staining (36).

P53 mutation analysis. Genomic DNA was extracted from paraffin-embedded blocks of 37 ESCC tumors by using a QIAamp DNA FFPE Tissue Kit ${ }^{\circledR}$ (Qiagen) according to the manufacturer's instructions. Exons 5-8 of the P53 gene were amplified by PCR by using previously described primers (37). Both strands of all PCR products were directly sequenced by using the BigDye ${ }^{\circledR}$ Terminator v3.1 (Applied Biosystems) and analyzed with an ABI PRISM ${ }^{\circledR} 3100$ Genetic Analyzer (Applied Biosystems). All mutations were confirmed by independent PCR reactions and sequencing.

Cell cultures. Human esophageal squamous cell carcinoma cell lines TE- 1 and TE-10 were purchased from the RIKEN BRC (Tsukuba, Japan). TE-1 is known to express a temperaturesensitive mutant P53 protein (codon 272, valine to methionine), which is capable of binding to specific DNA consensus sequences at $32^{\circ} \mathrm{C}$ but not at $37^{\circ} \mathrm{C}(38)$. TE- 10 cells express a mutant P53 protein (codon 242, cysteine to tyrosine) that displays no specific DNA-binding activity (39). Cells were cultured at $37^{\circ} \mathrm{C}$ in RPMI-1640 (Sigma-Aldrich) supplemented with $10 \%$ FBS (Invitrogen), penicillin/streptomycin, and L-glutamine (Invitrogen) under a $5 \% \mathrm{CO}_{2}$ atmosphere.

RNA isolation and real-time RT PCR. TE-1 cells and TE-10 cells were seeded in 6-well culture plates at a density of $1 \times 10^{5}$ cells per well, and after incubation at $37^{\circ} \mathrm{C}$ for $24 \mathrm{~h}$, the temperature was changed to $32^{\circ} \mathrm{C}$ or maintained at $37^{\circ} \mathrm{C}$, and the cells were harvested $24 \mathrm{~h}$ later. Total RNA was isolated with TRIzol ${ }^{\circledR}$ Reagent (Invitrogen) and transcribed into cDNA by using a PrimeScript ${ }^{\mathrm{TM}}$ RT Reagent Kit (Takara) according to the manufacturer's directions. Real-time PCR was performed in a Smart Cycler $^{\circledR}$ System (Takara) with SYBR ${ }^{\circledR}$ Premix Ex Taq ${ }^{\mathrm{TM}}$ (Takara). Expression of EZH2, MDM2, and P21 was normalized to that of GAPDH, and the relative expression level was calculated. The following PCR primer pairs were used: EZH2 5'-CCCTGACCTCTGTCTTA 
A

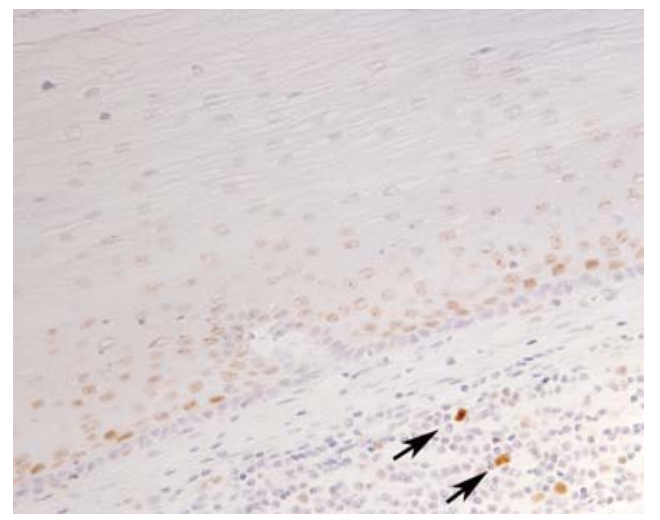

C

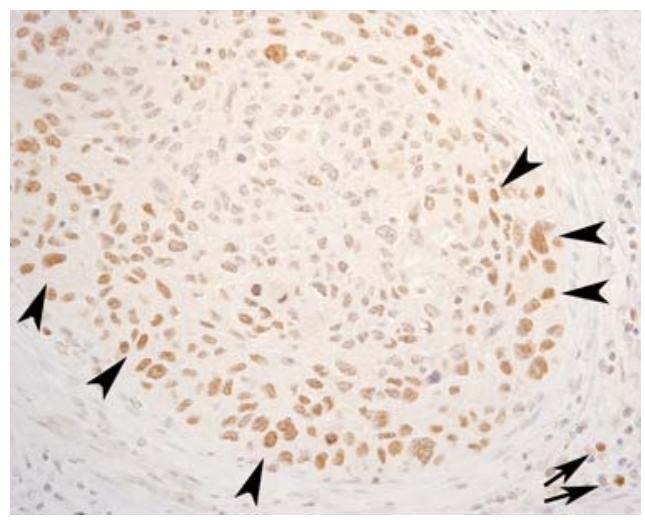

E

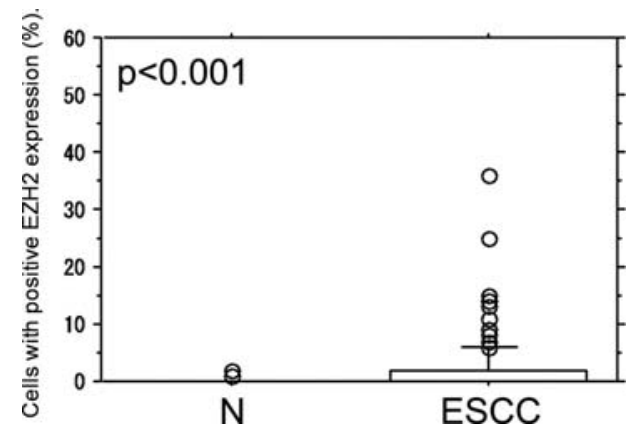

B

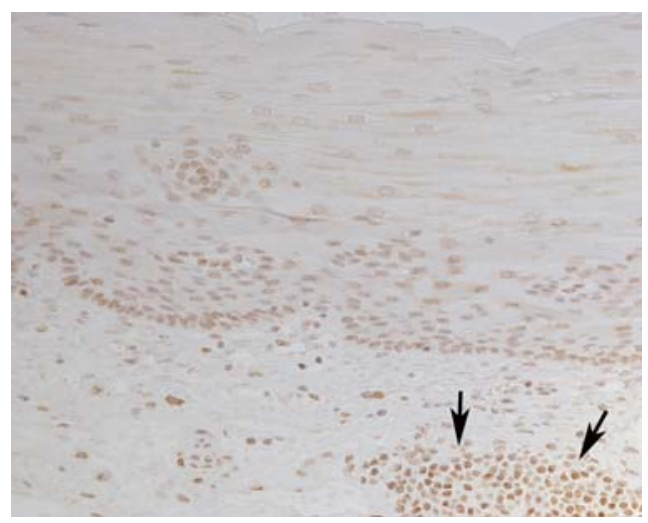

D

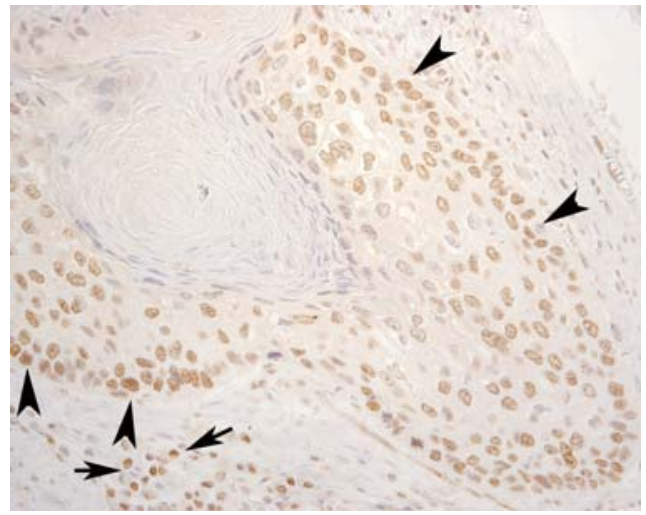

F

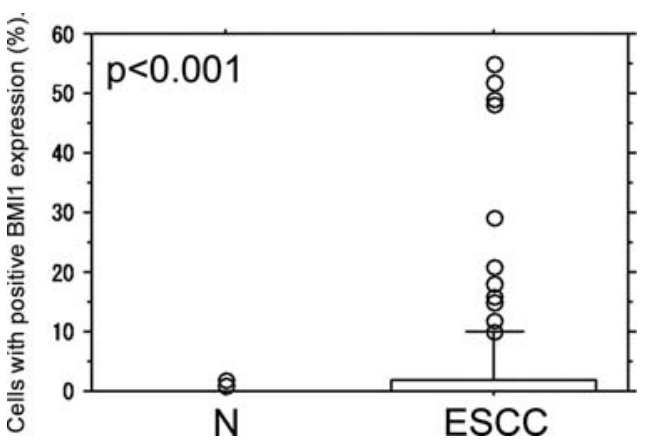

Figure 1. EZH2 and BMI1 expression in non-neoplastic adjacent esophageal squamous epithelium and ESCC. (A and B) Immunostaining of EZH2 protein (A) and BMI1 protein (B) in non-neoplastic adjacent squamous epithelium (original magnification x200). Weak immunostaining for EZH2 and BMI1 was observed in parabasal cells (A) and basal and parabasal cells (B), respectively. Note the intense immunostaining in the lymphocytes (arrows). (C and D) Immunostaining of EZH2 protein (C) and BMI1 protein (D) in ESCC tissue (original magnification x200). Weak EZH2 and BMI1 staining was predominantly observed in the periphery of the cancer cell nest. Some cancer cells show intense nuclear immunostaining (arrowheads) similar to the immunostaining in the lymphocytes (arrows). (E and F) Percentages of cells positive for EZH2 protein (E) and BMI1 protein (F) in non-neoplastic adjacent squamous epithelium and ESCC tissue. $\mathrm{N}$, non-neoplastic adjacent squamous epithelium.

CTTGTGGA-3' (forward) and 5'-ACGTCAGATGGTGCCA GCAATA-3' (reverse), GAPDH 5'-GCACCGTCAAGGCTG AGAAC-3' (forward) and 5'-ATGGTGGTGAAGACGCC AGT-3' (reverse), MDM2 5'-TGTTGGTGCACAAAAAG ACA-3' (forward) and 5'-CACGCCAAACAAATCTCCTA-3' (reverse), and P21 5'-CTGGAGACTCTCAGGGTCGAA-3' (forward) and 5'-GCGGATTAGGGCTTCCTCTT-3' (reverse).

Statistical analysis. Associations between aberrant expression of EZH2 and BMI1 and clinicopathological features and expression of other proteins were evaluated by using Fisher's exact test. Differences in the levels of expression of EZH2 and BMI1 in tissue samples and cell lines were analyzed by Student's t-test. Cumulative survival curves were drawn by the Kaplan-Meier method, and differences between the curves were analyzed by the log-rank test. All p-values were two-sided, and a $\mathrm{p}<0.05$ was considered significant. All analyses were performed by using the StatView version 5.0 for Windows software program (SAS Institute Inc. Cary, NC, USA).

\section{Results}

Expression of EZH2 and BMI1 in ESCC tissue and adjacent non-neoplastic squamous epithelium. Immunohistochemical staining for EZH2 protein and BMI1 protein in non-neoplastic squamous epithelium adjacent to cancer tissue was available in 115 and 110, respectively, of the 136 ESCC cases. Examination of the non-neoplastic squamous epithelium revealed weak EZH2 immunostaining in the nuclei of parabasal cells and no immunostaining in the basal cells or terminally differentiated cells near the surface (Fig. 1A). Weak BMI1 
Table I. Association between aberrant expression of EZH2 and BMI1 and clinicopathological findings in ESCC.

\begin{tabular}{|c|c|c|c|c|c|c|}
\hline & \multicolumn{3}{|c|}{ EZH2 aberrant expression } & \multicolumn{3}{|c|}{ BMI1 aberrant expression } \\
\hline & $\begin{array}{c}\text { Positive } \\
(n=19)\end{array}$ & $\begin{array}{c}\text { Negative } \\
(n=117)\end{array}$ & p-value & $\begin{array}{l}\text { Positive } \\
(n=23)\end{array}$ & $\begin{array}{l}\text { Negative } \\
(n=113)\end{array}$ & p-value \\
\hline \multicolumn{7}{|l|}{ Age } \\
\hline$\geq$ median & 11 & 58 & 0.623 & 12 & 57 & $>0.999$ \\
\hline$<$ median & 8 & 59 & & 11 & 56 & \\
\hline \multicolumn{7}{|l|}{ Gender } \\
\hline Male & 14 & 100 & 0.194 & 19 & 95 & $>0.999$ \\
\hline Female & 5 & 17 & & 4 & 18 & \\
\hline \multicolumn{7}{|l|}{ Tumor size ${ }^{b}$} \\
\hline$\geq$ median & 14 & 59 & $0.041^{\mathrm{a}}$ & 13 & 60 & 0.823 \\
\hline$<$ median & 4 & 58 & & 10 & 52 & \\
\hline \multicolumn{7}{|l|}{ Histological grade } \\
\hline Well/moderately differentiated & 16 & 95 & $>0.999$ & 18 & 93 & 0.768 \\
\hline Poorly differentiated & 3 & 22 & & 5 & 20 & \\
\hline \multicolumn{7}{|l|}{ Depth of invasion } \\
\hline $\mathrm{T} 1$ & 3 & 54 & $0.013^{\mathrm{a}}$ & 11 & 46 & 0.644 \\
\hline $\mathrm{T} 2 / \mathrm{T} 3 / 4$ & 16 & 63 & & 12 & 67 & \\
\hline \multicolumn{7}{|l|}{ Lymph node metastasis } \\
\hline Positive & 13 & 68 & 0.458 & 8 & 73 & $0.010^{\mathrm{a}}$ \\
\hline Negative & 6 & 49 & & 15 & 40 & \\
\hline \multicolumn{7}{|l|}{ Distant metastasis } \\
\hline Positive & 3 & 3 & $0.036^{\mathrm{a}}$ & 0 & 6 & 0.589 \\
\hline Negative & 16 & 114 & & 23 & 107 & \\
\hline \multicolumn{7}{|l|}{ Lymphatic invasion } \\
\hline Positive & 10 & 56 & 0.806 & 7 & 59 & 0.069 \\
\hline Negative & 9 & 61 & & 16 & 54 & \\
\hline \multicolumn{7}{|l|}{ Venous invasion } \\
\hline Positive & 12 & 69 & 0.805 & 7 & 24 & $0.002^{\mathrm{a}}$ \\
\hline Negative & 7 & 48 & & 16 & 39 & \\
\hline \multicolumn{7}{|l|}{ Stage } \\
\hline I/IIA/IIB & 8 & 78 & 0.070 & 16 & 70 & 0.636 \\
\hline III/IV & 11 & 39 & & 7 & 43 & \\
\hline
\end{tabular}

Number of cases are shown. ${ }^{\mathrm{a}} \mathrm{p}<0.05 .{ }^{\mathrm{b}}$ Tumor size was not available in one case.

immunostaining was observed in the nuclei of basal and parabasal cells (Fig. 1B). However, few non-neoplastic epithelial cells showed EZH2 or BMI1 immunostaining that was as intense as in the nuclei of the lymphocytes. Examination of the ESCC tissue revealed weak EZH2 and BMI1 staining in the majority of the cancer cells. In the differentiated type ESCCs, weak immunostaining for EZH2 protein and BMI1 protein was predominantly present in the periphery of the cancer cell nests and was almost absent in the center. Immunostaining in the nuclei of some cells was as intense as in the lymphocytes, and they were judged to be positive for expression of the respective protein (Fig. 1C and D). The percentages of nuclei that were positive for either EZH2 or
BMI1 were significantly higher in the ESCC tissue than in adjacent non-neoplastic squamous epithelium (Fig. 1E and F).

Aberrant expression of EZH2 and BMI1 in ESCC tissue and its association with clinicopathological parameters and outcome. Aberrant expression of EZH2 protein was observed in 19 of the 136 ESCCs (14.0\%), and it was significantly associated with larger size, greater depth of invasion, and the presence of distant metastasis. Aberrant expression of BMI1 protein was observed in 23 of the 136 ESCCs (16.9\%), and it was inversely associated with lymph node metastasis and venous invasion (Table I). ESCC patients with aberrant EZH2 expression had a significantly shorter disease-free 
A

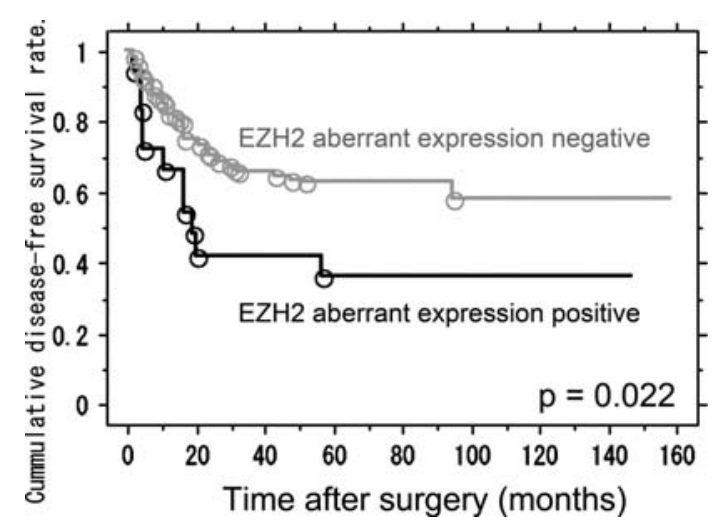

B

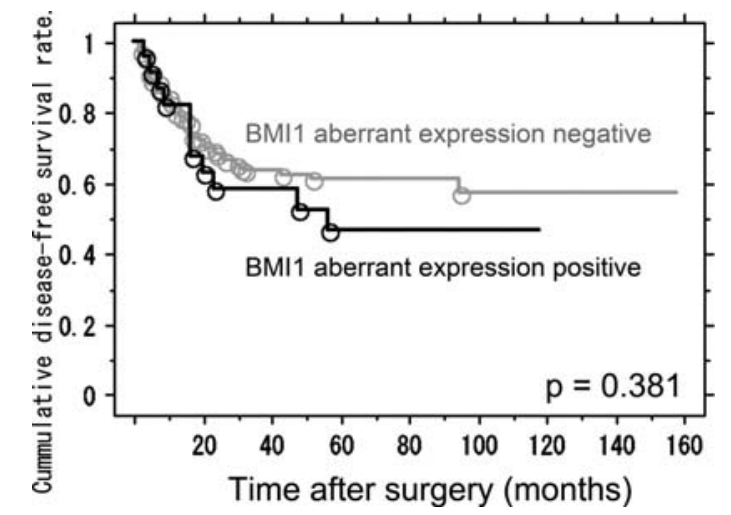

Figure 2. Kaplan-Meier disease-free survival curves of ESCC patients according to whether aberrant expression of EZH2 (A) and BMI1 (B) was present.

survival time. There was no association between aberrant BMI1 expression and the survival time of ESCC patients (Fig. 2).

Association between aberrant EZH2 expression and other biological factors. To identify biological factors associated with aberrant expression of EZH2 protein, we evaluated expression of MYC, RB, and P53 protein immunohistochemically in 37 ESCCs consisting of 19 that were positive for aberrant EZH2 expression and 18 that were negative. As shown in Table II, aberrant EZH2 expression was significantly associated with P53 protein expression, and we then confirmed the association in all 136 cases as a whole (data not shown). Neither MYC nor RB expression was significantly associated with aberrant EZH2 expression (Table II). Genomic DNA adequate for P53 mutation analysis was available from 15 of the 37 ESCCs, and the results revealed six mutations within exons 5-8 of the P53 gene in five cases. Five of the six mutations were missense mutations associated with an amino acid substitution and the other was a nonsense mutation. In three cases there was both a missense mutation(s) in the P53 gene and positive P53 immunostaining, and all the three cases were positive for aberrant EZH2 expression. In 10 cases there were no P53 mutations and immunostaining for P53 was negative. Six of them were negative for aberrant EZH2 expression, and four were positive. In one case there was a nonsense mutation in exon 7 of the P53 gene and positive P53 immunostaining, and in another case there was a missense mutation in exon 8
A

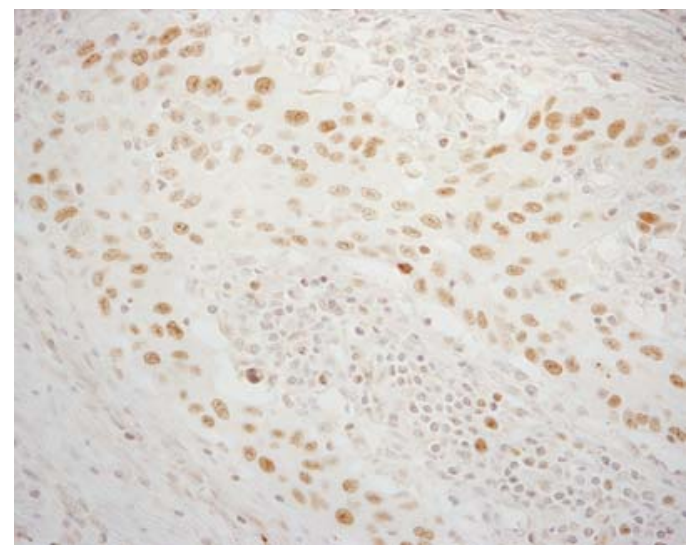

B

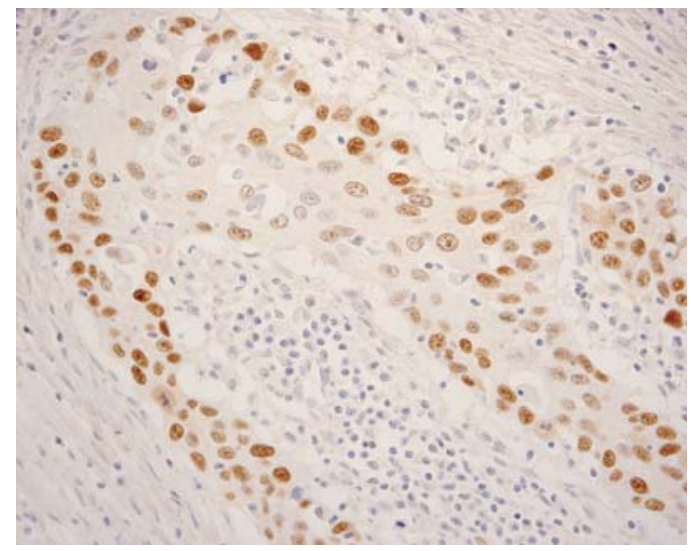

C

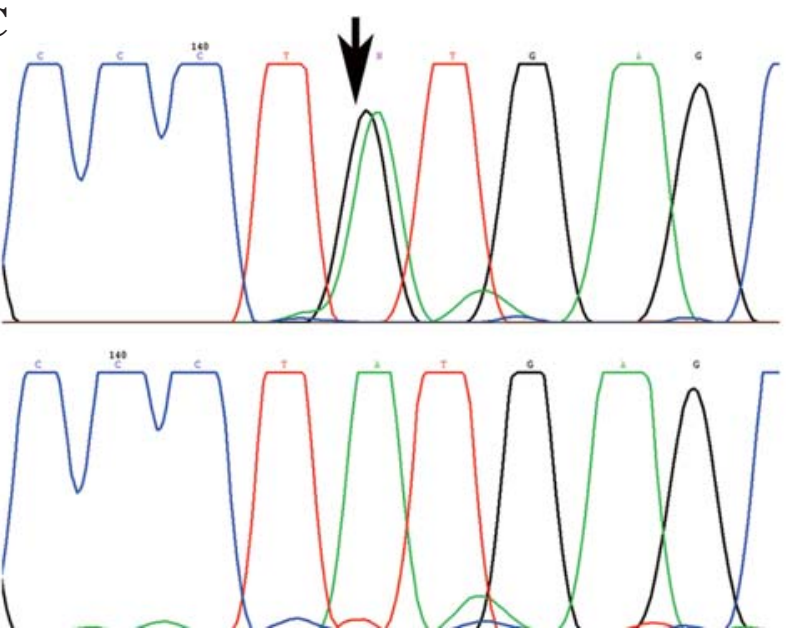

Figure 3. A representative case of ESCC with aberrant EZH2 expression accompanied by P53 alteration. Immunohistochemistry revealing aberrant expression of EZH2 (A). Immunostaining of serial sections showing positive P53 protein expression (B). Direct sequencing analysis in this case revealed a missense mutation in exon 6 of the P53 gene (codon 220; TAT $\rightarrow$ TGT, arrow). The bottom chromatograph represents the wild-type sequence obtained by analyzing a normal lymph node sample (C).

of the P53 gene and negative P53 immunostaining, and both cases were negative for aberrant expression of EZH2 (Fig. 3 and Table III).

Association between transcriptional activity of P53 and EZH2 expression in ESCC cell lines. TE-1 cells express a mutant P53 protein that is capable of binding to specific 
Table II. Association between EZH2 aberrant expression and expression of MYC, RB, P53, and in 37 cases with ESCC.

\begin{tabular}{lccc}
\hline & \multicolumn{3}{c}{ EZH2 aberrant expression } \\
\cline { 2 - 4 } & $\begin{array}{c}\text { Positive } \\
(\mathrm{n}=19)\end{array}$ & $\begin{array}{c}\text { Negative } \\
(\mathrm{n}=18)\end{array}$ & $\mathrm{p}$-value \\
\hline MYC & & & \\
High & 9 & 10 & 0.746 \\
Low & 10 & 8 & 0.746 \\
RB & & & \\
High & 9 & 10 & $0.003^{\mathrm{a}}$ \\
Low & 10 & & \\
P53 & & 4 & \\
Positive & 14 & 14 & \\
Negative & 5 & & \\
\hline
\end{tabular}

Number of cases are shown. ${ }^{\mathrm{a}} \mathrm{p}<0.05$.

DNA consensus sequences and that exhibits transcriptional activity at $32^{\circ} \mathrm{C}$ but not at $37^{\circ} \mathrm{C}(38)$. Consistent with these characteristics we observed significant upregulation of the P53 target genes MDM2 and P21 when TE-1 cells were

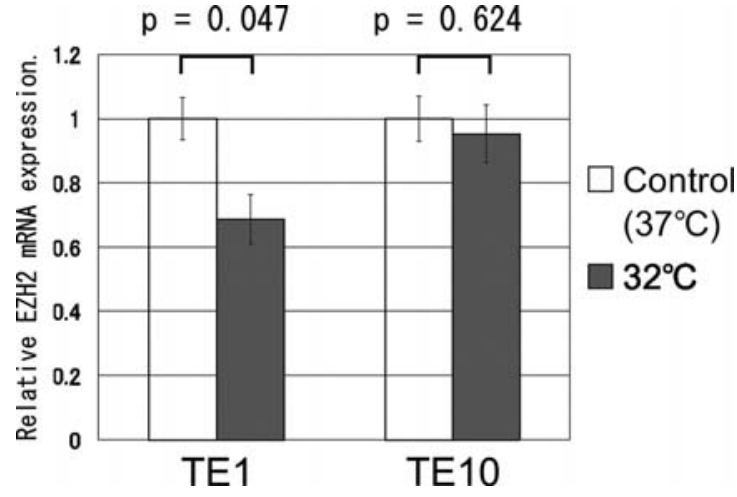

Figure 4. Association between EZH2 expression and P53 transcriptional activity in ESCC cell lines. TE- 1 cells express a mutant P53 protein that exhibits transcriptional activity at $32^{\circ} \mathrm{C}$ but not at $37^{\circ} \mathrm{C}$. Expression of EZH2 mRNA in TE-1 cells was significantly lower when cultured at $32^{\circ} \mathrm{C}$ than when cultured at $37^{\circ} \mathrm{C}$. By contrast, TE- 10 cells express a mutant P53 protein that has no specific DNA-binding activity, and there was no significant difference in EZH2 mRNA expression between cells cultured at 32 and $37^{\circ} \mathrm{C}$. Relative levels of EZH2 mRNA expression normalized to the level of GAPDH expression are shown.

cultured at $32^{\circ} \mathrm{C}$ (data not shown) and expression of EZH2 mRNA in TE-1 cells was significantly lower when cultured at $32^{\circ} \mathrm{C}$ than at $37^{\circ} \mathrm{C}$. By contrast, when cultured at 32 and $37^{\circ} \mathrm{C}$ there was no significant difference in EZH2 mRNA expression by TE-10 cells, which express a mutant P53 protein without specific DNA-binding activity (Fig. 4).

Table III. Mutations in the P53 gene detected in the present study.

\begin{tabular}{|c|c|c|c|c|c|c|}
\hline \multirow[b]{2}{*}{$\begin{array}{l}\text { No. of } \\
\text { cases }\end{array}$} & \multicolumn{4}{|c|}{ P53 mutation } & \multirow[b]{2}{*}{$\begin{array}{l}\text { P53 protein } \\
\text { expression }\end{array}$} & \multirow[b]{2}{*}{$\begin{array}{c}\text { EZH2 aberrant } \\
\text { expression }\end{array}$} \\
\hline & Exon & Codon & $\begin{array}{l}\text { Nucleotide } \\
\text { substitution }\end{array}$ & $\begin{array}{l}\text { Amino acid } \\
\text { substitution }\end{array}$ & & \\
\hline 1 & 6 & 220 & $\mathrm{TAT} \rightarrow \mathrm{TGT}$ & Tyr $\rightarrow$ Cys & Positive & Positive \\
\hline 2 & None & None & None & None & Negative & Negative \\
\hline 3 & None & None & None & None & Negative & Negative \\
\hline 4 & None & None & None & None & Negative & Positive \\
\hline 5 & None & None & None & None & Negative & Negative \\
\hline 6 & 7 & 258 & $\mathrm{GAA} \rightarrow \mathrm{TAA}$ & Stop & Positive & Negative \\
\hline 7 & None & None & None & None & Negative & Negative \\
\hline 8 & None & None & None & None & Negative & Negative \\
\hline $9^{\mathrm{a}}$ & 5 & 151 & $\mathrm{CCC} \rightarrow \mathrm{GCC}$ & $\mathrm{Pro} \rightarrow$ Ala & Positive & Positive \\
\hline $9^{\mathrm{a}}$ & 6 & 214 & $\mathrm{CAT} \rightarrow \mathrm{CGT}$ & His $\rightarrow$ Arg & Positive & Positive \\
\hline 10 & None & None & None & None & Negative & Negative \\
\hline 11 & 8 & 273 & $\mathrm{CGT} \rightarrow \mathrm{CAT}$ & Arg $\rightarrow$ His & Positive & Positive \\
\hline 12 & None & None & None & None & Negative & Positive \\
\hline 13 & 8 & 285 & $\mathrm{GAG} \rightarrow \mathrm{AAG}$ & Glu $\rightarrow$ Lys & Negative & Negative \\
\hline 14 & None & None & None & None & Negative & Positive \\
\hline 15 & None & None & None & None & Negative & Positive \\
\hline
\end{tabular}

${ }^{\mathrm{a}}$ Case 9 had two different mutations in exons 5 and 6. 


\section{Discussion}

In this study, we observed immunostaining for EZH2 protein and BMI1 protein in both non-neoplastic and ESCC tissues. In non-neoplastic esophageal squamous epithelium, we found weak staining for EZH2 in the nuclei of parabasal cells, and for BMI1 in the nuclei of both basal and parabasal cells. Few cells showed intense immunostaining, and the percentages of cells with nuclear immunostaining for either EZH2 or BMI1 that was as intense or more intense than in the nuclei of lymphocytes never exceeded $5 \%$. On the other hand, weak EZH2 and BMI1 immunostaining was observed in the majority of the cancer cells, and some cancer cells showed intense immunostaining for EZH2 or BMI1 or both. In fact, the percentages of nuclei with intense immunostaining for either EZH2 or BMI1 were greater than $5 \%$ in some ESCCs, and they were significantly higher in the ESCC tissue than in the adjacent non-neoplastic squamous epithelium of the esophagus (Fig. 1E and F). We therefore concluded that intense expression of either EZH2 or BMI1 was characteristic of ESCC cells, and classified tumors in which $5 \%$ or more of the cancer cells exhibited intense immunostaining as exhibiting aberrant expression of the respective protein. Based on this criterion, aberrant expression of EZH2 and BMI1 was present in 14.0 and $16.9 \%$, respectively, of the ESCCs.

The results of this study also demonstrated that aberrant expression of EZH2 protein was associated with larger tumor size, greater depth of invasion, presence of distant metastasis, and more remarkably, a shorter disease-free survival time of ESCC patients. Our data are consistent with previous reports that showed significant relations between EZH2 expression and metastasis, invasion, and poor outcome in other types of human cancers $(2,4-8)$. Recently, He et al examined protein expression of EZH2 in pretreatment biopsy specimen of ESCC treated with chemoradiotherapy, and found that high EZH2 expression was correlated with poor progressionfree survival and poor disease specific survival (40). Taken together, it is suggested that dysregulated expression of EZH2 is significantly associated with aggressive nature of ESCC in both surgery and chemoradiotherapy treated patients.

On the other hand, the results also showed that aberrant expression of BMI1 was negatively associated with lymph node metastasis and venous invasion. However, in spite of such favorable clinicopathological characteristics in BMI1-positive cases, there was no significant association between aberrant BMI1 expression and outcome. Conflicting data have been reported in this connection: while overexpression of BMI1 has been shown to be associated with an unfavorable outcome in some reports $(22,25,26,41,42)$, others have shown that it was not $(20,43,44)$. The reason for such conflicting findings regarding associations between aberrant expression of BMI1 and the clinicopathological findings is unknown.

An interesting finding in this study was that among the several molecules which have been reported to be involved in $\mathrm{EZH} 2$ regulation and are also known to have an important role in ESCC development, aberrant expression of EZH2 was significantly associated with expression of only P53 protein in ESCC tissue. Consistent with this finding, intense EZH2 expression was rarely seen in non-neoplastic esophageal epithelium, where P53 protein expression was negative in most cells. We also analyzed mutations in exons 5-8 of the P53 gene in selected cases, and all three ESCCs with both a missense mutation(s) and protein expression of P53 were positive for aberrant EZH2 expression. These findings were consistent with the results of a study by Pietersen et al that demonstrated a positive association between high EZH2 expression and either P53 mutation or P53 protein expression in breast cancer (20). In agreement with the observation in the ESSC tissue samples described above, EZH2 expression in TE-1 cells was significantly reduced when cultured at $32^{\circ} \mathrm{C}$. Since TE- 1 cells express a mutant P53 protein that exhibits transcriptional activity at $32^{\circ} \mathrm{C}$, but not at $37^{\circ} \mathrm{C}(38)$, our findings suggest that impaired transcriptional activity of P53 protein may cause upregulation of EZH2 in TE1 cells. Taken together, our observations suggest that P53 alteration and impaired transcriptional activity may have a role in the dysregulation of EZH2 expression in ESCC cells. However, since several cases that were positive for aberrant EZH2 expression showed no mutation or protein expression of P53, additional factor(s) other than P53 alteration may be involved in the aberrant expression of EZH2. Indeed, it is reported that the amplification of the EZH2 gene is detected in some ESCCs (40).

In conclusion, expression of EZH2 and BMI1 was found to be significantly upregulated in ESCC tissue in comparison with adjacent non-neoplastic squamous epithelium. Aberrant EZH2 expression in ESCC was found to be significantly associated with larger tumor size, greater depth of invasion, and presence of distant metastasis, and ESCC patients with aberrant EZH2 expression had a significantly shorter diseasefree survival time. In addition, aberrant EZH2 expression was found to be significantly associated with P53 alteration. Taken together, our findings suggest that P53 alteration may be involved in dysregulation of EZH2 expression and that aberrant expression of EZH2 may play a role in the progression of ESCC.

\section{Acknowledgments}

We thank Ms. Mai Okumoto, Ms. Hiroko Hashimoto, and Ms. Sachiko Fukuda for their excellent technical support. This work was supported in part by the program for promotion of Fundamental Studies in Health Sciences of the National Institute of Biomedical Innovation, in part by a Grant-in-Aid for the Third Comprehensive 10-Year Strategy for Cancer Control and for Cancer Research (16-15) from the Ministry of Health, Labour and Welfare of Japan. A.Y. was awardee of Research Resident Fellowships from the Foundation for Promotion of Cancer Research (Japan) for the 3rd Term Comprehensive 10-Year Strategy for Cancer Control.

\section{References}

1. Sparmann A and van Lohuizen M: Polycomb silencers control cell fate, development and cancer. Nat Rev Cancer 6: 846-856, 2006.

2. Varambally S, Dhanasekaran SM, Zhou M, Barrette TR, Kumar-Sinha C, Sanda MG, Ghosh D, Pienta KJ, Sewalt RGAB, Otte AP, Rubin MA and Chinnaiyan AM: The polycomb group protein EZH2 is involved in progression of prostate cancer. Nature 419: 624-629, 2002. 
3. Kleer CG, Cao Q, Varambally S, Shen R, Ota I, Tomlins SA, Ghosh D, Sewalt RGAB, Otte AP, Hayes DF, Sabel MS, Livant D, Weiss SJ, Rubin MA and Chinnaiyan AM: EZH2 is a marker of aggressive breast cancer and promotes neoplastic transformation of breast epithelial cells. Proc Natl Acad Sci USA 100: 11606-11611, 2003.

4. Laitinen S, Martikainen PM, Tolonen T, Isola J, Tammela TLJ and Visakorpi T: EZH2, Ki-67 and MCM7 are prognostic markers in prostatectomy treated patients. Int J Cancer 122 595-602, 2008

5. Collett K, Eide GE, Arnes J, Stefansson IM, Eide J, Braaten A, Aas T, Otte AP and Akslen LA: Expression of enhancer of zeste homologue 2 is significantly associated with increased tumor cell proliferation and is a marker of aggressive breast cancer. Clin Cancer Res 12: 1168-1174, 2006

6. Mimori K, Ogawa K, Okamoto T, Sudo T, Inoue H and Mori M: Clinical significance of enhancer of zeste homolog 2 expression in colorectal cancer cases. Eur J Surg Oncol 31: 376-380, 2005 .

7. Matsukawa Y, Semba S, Kato H, Ito A, Yanagihara K and Yokozaki H: Expression of the enhancer of zeste homolog 2 is correlated with poor prognosis in human gastric cancer. Cancer Sci 97: 484-491, 2006

8. Kidani K, Osaki M, Tamura T, Yamaga K, Shomori K, Ryoke K and Ito H: High expression of EZH2 is associated with tumor proliferation and prognosis in human oral squamous cell carcinomas. Oral Oncol 45: 39-46, 2009.

9. Bracken AP, Pasini D, Capra M, Prosperini E, Colli E and Helin K: EZH2 is downstream of the pRB-E2F pathway, essential for proliferation and amplified in cancer. EMBO J 22: 5323-5335, 2003.

10. Tang X, Milyavsky M, Shats I, Erez N, Goldfinger N and Rotter V: Activated p53 suppresses the histone methyltransferase EZH2 gene. Oncogene 23: 5759-5769, 2004.

11. Croonquist PA and van Ness B: The polycomb group protein enhancer of zeste analog 2 (EZH2) is an oncogene that influences myeloma cell growth and the mutant ras phenotype. Oncogene 24: 6269-6280, 2005.

12. Bryant RJ, Cross NA, Eaton CL, Hamdy FC and Cunliffe VT: EZH2 promotes proliferation and invasiveness of prostate cancer cells. Prostate 67: 547-556, 2007.

13. Visser HPJ, Gunster MJ, Kluin-Nelemans HC, Manders EMM, Raaphorst FM, Meijer CJLM, Willemze R and Otte AP: The polycomb group protein EZH2 is upregulated in proliferating, cultured human mantle cell lymphoma. Br J Haematol 112: 950-958, 2001.

14. Chen H, Tu SW and Hsieh JT: Down-regulation of human DAB2IP gene expression mediated by polycomb Ezh2 complex and histone deacetylase in prostate cancer. J Biol Chem 280: 22437-22444, 2005.

15. Fujii S and Ochiai A: Enhancer of zeste homolog 2 downregulates E-cadherin by mediating histone $\mathrm{H} 3$ methylation in gastric carcinoma cells. Cancer Sci 99: 738-746, 2008.

16. Fujii S, Ito K, Ito Y and Ochiai A: Enhencer of zeste homologue 2 (EZH2) down-regulates RUNX3 by increasing histone $\mathrm{H} 3$ methylation. J Biol Chem 283: 17324-17332, 2008.

17. Sander S, Bullinger L, Klapproth K, Fiedler K, Kestler HA, Barth TF, Möller P, Stilgenbauer S, Pollack JR and Wirth T: MYC stimulates EZH2 expression by repression of its negative regulator miR-26a. Blood 112: 4202-4212, 2008.

18. Wong CF and Tellam RL: MicroRNA-26a targets the histone methyltransferase Enhancer of Zeste homolog 2 during myogenesis. J Biol Chem 283: 9836-9843, 2008.

19. Varambally S, Cao Q, Mani RS, Shankar S, Wang X, Ateeq B, Laxman B, Cao X, Jing X, Ramnarayanan K, Brenner JC, Yu J, Kim JH, Han B, Tan P, Kumar-Sinha C, Lonigro RJ, Palanisamy N, Maher CA and Chinnaiyan AM: Genomic loss of microRNA-101 leads to overexpression of histone methyltransferase EZH2 in cancer. Science 322: 1695-1699, 2008 .

20. Pietersen AM, Horlings HM, Hauptmann M, Langer $\not d$ A, Ajouaou A, Cornelissen-Steijger P, Wessels LF, Jonkers J, van de Vijver MJ and van Lohuizen M: EZH2 and BMI1 inversely correlated with prognosis and TP53 mutation in breast cancer. Breast Cancer Res 10: R109, 2008

21. Kim JH, Yoon SY, Kim CN, Joo JH, Moon SK, Choe IS, Choe YK and Kim JW: The Bmi-1 oncoprotein is overexpressed in human colorectal cancer and correlates with the reduced p16INK4a/p14ARF proteins. Cancer Lett 203: 217-224, 2004.
22. Song LB, Zeng MS, Liao WT, Zhang L, Mo HY, Liu WL, Shao JY, Wu QL, Li MZ, Xia YF, Fu LW, Huang WL, Dimri GP, Band V and Zeng YX: Bmi-1 is a novel molecular marker of nasopharyngeal carcinoma progression and immortalizes primary human nasopharyngeal epithelial cells. Cancer Res 66: 6225-6232, 2006.

23. Kang MK, Kim RH, Kim SJ, Yip FK, Shin KH, Dimri GP, Christensen R, Han T and Park NH: Elevated Bmi-1 expression is associated with dysplastic cell transformation during oral carcinogenesis and is required for cancer cell replication and survival. Br J Cancer 96: 126-133, 2007.

24. Sasaki M, Ikeda H, Itatsu K, Yamaguchi J, Sawada S, Minato H, Ohta T and Nakanuma Y: The overexpression of polycomb group proteins Bmi1 and EZH2 is associated with the progression and aggressive biological behavior of hepatocellular carcinoma. Lab Invest 88: 873-882, 2008.

25. Yonemitsu Y, Imazeki F, Chiba T, Fukai K, Nagai Y, Miyagi S, Arai M, Aoki R, Miyazaki M, Nakatani Y, Iwama A and Yokosuka O: Distinct expression of polycomb group proteins EZH2 and BMI1 in hepatocellular carcinoma. Hum Pathol 40: 1304-1311, 2009

26. Qin ZK, Yang JA, Ye YL, Zhang X, Xu LH, Zhou FJ, Han H, Liu ZW, Song LB and Zeng MS: Expression of Bmi-1 is a prognostic marker in bladder cancer. BMC Cancer 9: 61, 2009.

27. Steele JC, Torr EE, Noakes KL, Kalk E, Moss PA, Reynolds GM, Hubscher SG, van Lohuizen M, Adams DH and Young LS: The polycomb group proteins, BMI-1 and EZH2, are tumourassociated antigens. Br J Cancer 95: 1202-1211, 2006.

28. Komohara Y, Harada M, Arima Y, Suekane S, Noguchi M, Yamada A, Itoh K and Matsuoka K: Anti-cancer vaccine candidates in specific immunotherapy for bladder carcinoma. Int J Oncol 29: 1555-1560, 2006.

29. Komohara Y, Harada M, Arima Y, Suekane S, Noguchi M, Yamada A, Itoh $\mathrm{K}$ and Matsuoka K: Identification of target antigens in specific immunotherapy for renal cell carcinoma. J Urol 177: 1157-1162, 2007.

30. Tan J, Yang X, Zhuang L, Jiang X, Chen W, Lee PL, Karuturi RK, Tan PB, Liu ET and Yu Q: Pharmacologic disruption of polycomb-repressive complex 2-mediated gene repression selectively induces apoptosis in cancer cells. Genes Dev 21: 1050-1063, 2007.

31. Hamilton SR, Aaltonen LA (eds): World Health Organization classification of tumors: pathology and genetics of tumors of the digestive system. IARC Press, Lyon, pp11-19, 2000.

32. Yasuda M, Kuwano H, Watanabe M, Toh Y, Ohno S and Sugimachi K: p53 expression in squamous dysplasia associated with carcinoma of the oesophagus: evidence for field carcinogenesis. Br J Cancer 83: 1033-1038, 2000.

33. Egashira A, Morita M, Kakeji Y, Sadanaga N, Oki E, Honbo T, Ohta $\mathrm{M}$ and Maehara Y: p53 gene mutations in esophageal squamous cell carcinoma and their relevance to etiology and pathogenesis: results in Japan and comparisons with other countries. Cancer Sci 98: 1152-1156, 2007.

34. Kaneko K, Katagiri A, Konishi K, Kurahashi T, Ito H, Kumekawa Y, Yamamoto T, Muramoto T, Kubota Y, Nozawa H, Makino R, Kushima M and Imawari M: Study of P53 gene alteration as a biomarker to evaluate the malignant risk of Lugol-unstained lesion with non-dysplasia in the oesophagus. Br J Cancer 96: 492-498, 2007.

35. Sobin LH and Wittekind C (eds): TNM Classification of Malignant Tumors. 6th edition. Wiley-Liss, New York, NY, pp60-64, 2002.

36. Oota M, Takeda A, Leu TL, Okazumi S, Matsubara H, Funami Y, Nabeya Y, Kobayashi S, Gunji Y, Suzuki T, Ochiai T and Shimada H: Prognostic significance of thymidine phosphorylase and p53 co-expression in esophageal squamous cell carcinoma. Oncol Rep 9: 23-28, 2002.

37. Patocs A, Zhang L, Xu Y, Weber F, Caldes T, Mutter GL, Platzer P and Eng C: Breast-cancer stromal cells with TP53 mutations and nodal metastasis. N Engl J Med 357: 2543-2551, 2007.

38. Guimaraes DP, Oliveira IM, De Moraes E, Paiva GR, Souza DM, Barnas C, Olmedo DB, Pinto CE, Faria PA, De Moura Gallo CV, Small IA, Ferreira CG and Hainaut P: Interferon-inducible guanylate binding protein (GBP)-2: a novel p53-regulated tumor marker in esophageal squamous cell carcinomas. Int J Cancer 124: 272-279, 2009.

39. Barnas C, Martel-Planche G, Furukawa Y, Hollstein M, Montesano R and Hainaut P: Inactivation of the p53 protein in cell lines derived from human esophageal cancers. Int J Cancer 71: 79-87, 1997. 
40. He LR, Liu MZ, Li BK, Jia WH, Zhang Y, Liao YJ, Chen YC, Zhang LJ, Guan XY, Zeng YX, Kung HF and Xie D: High expression of EZH2 is associated with tumor aggressiveness and poor prognosis in patients with esophageal squamous cell carcinoma treated with definitive chemoradiotherapy. Int J Cancer 127: 138-147, 2010.

41. Wang H, Pan K, Zhang HK, Weng DS, Zhou J, Li JJ, Huang W, Song HF, Chen MS and Xia JC: Increased polycomb-group oncogene Bmi-1 expression correlates with poor prognosis in hepatocellular carcinoma. J Cancer Res Clin Oncol 134: 535-541, 2008.

42. Vrzalikova K, Skarda J, Ehrmann J, Murray PG, Fridman E, Kopolovic J, Knizetova P, Hajduch M, Klein J, Kolek V, Radova L and Kolar Z: Prognostic value of BMI-1 oncoprotein expression in NSNLC patients: a tissue microarray study. J Cancer Res Clin Oncol 134: 1037-1042, 2008.
43. Choi YJ, Choi YL, Cho EY, Shin YK, Sung KW, Hwang YK, Lee SJ, Kong G, Lee JE, Kim JS, Kim JH, Yang JH and Nam SJ: Expression of Bmi-1 protein in tumor tissue is associated with favorable prognosis in breast cancer patients. Breast Cancer Res Treat 113: 83-93, 2009.

44. Bachmann IM, Puntervoll HE, Otte AP and Akslen LA: Loss of BMI-1 expression is associated with clinical progress of malignant melanoma. Mod Pathol 21: 583-590, 2008. 